\title{
Influence of Coal Ash on the Concrete Properties and Its Performance Under Sulphate and Chloride Conditions
}

\section{Sajjad Ali Mangi}

Mehran University of Engineering and Technology https://orcid.org/0000-0003-4770-9108

Mohd Haziman Wan Ibrahim ( $\sim$ haziman@uthm.edu.my )

Universiti Tun Hussein Onn Malaysia

Norwati Jamaluddin

Universiti Tun Hussein Onn Malaysia

Mohd Fadzil Arshad

UiTM: Universiti Teknologi MARA

Shabir Hussain Khahro

Prince Sultan University

Ramadhansyah Putra Jaya

Universiti Malaysia Pahang

\section{Research Article}

Keywords: Coal bottom ash, cement replacement, sulphate-chloride attack, chloride penetration, drying shrinkage.

Posted Date: April 15th, 2021

DOI: https://doi.org/10.21203/rs.3.rs-373072/v1

License: (c) (1) This work is licensed under a Creative Commons Attribution 4.0 International License. Read Full License 


\section{Abstract}

This study investigated the influence of Coal Bottom Ash (CBA) on the concrete properties and evaluate the effects of combined exposure of sulphate and chloride conditions on the concrete containing CBA. During concrete mixing, cement was replaced with CBA by $10 \%$ of cement weight. Initially, concrete samples were kept in normal water for 28 days. Next, the specimens were moved to combined solution of $5 \%$ Sodium sulphate $\left(\mathrm{Na}_{2} \mathrm{SO}_{4}\right)$ and $5 \%$ sodium chloride $(\mathrm{NaCl})$ solution for further 28 to 180 days. The experimental findings demonstrated that the concrete containing 10\% CBA (M2) gives $12 \%$ higher compressive strength than the water cured normal concrete (M1). However, when it was exposed to solution of $5 \% \mathrm{Na}_{2} \mathrm{SO}_{4}$ and $5 \% \mathrm{NaCl}$, gives $0.2 \%$ greater compressive strength with reference to $\mathrm{M} 1$. The presence of $10 \%$ CBA decreases the chloride penetration and drying shrinkage around $33.6 \%$ and $29.2 \%$ respectively at 180 days. Hence, this study declared $10 \%$ CBA as optimum that can be used for future research.

\section{Introduction}

Coal is a source of energy to produce electricity. The burning of coal in a furnace of a power plant, results in the generation of noncombustible ashes like coal bottom ash (CBA) and fly ash (FA). Typically one megawatt electricity is produced through 15-18.75 tons burning of coal and left behind around 4.3 tons of CBA and 11 tons of FA (Asokan, Saxena, \& Asolekar, 2005). Approximately annual coal ash generation is about $600-800$ million tons worldwide (Hui, Hui, \& Lee, 2009). Coal ash that is removed from flue gases in an electro-precipitator is named as FA which is around $70-80 \%$ of total ash and remaining $20-$ $30 \%$ of heavyweight ash falls in to the bottom of furnace, called as CBA (Singh, Siddique, Ait-Mokhtar, \& Belarbi, 2015). In America, the coal-fired power plants produces around 22.6 million tons of FA and 3.8 million of CBA (ACAA, 2017), particularly Malaysian power plants contributes around 6.8 million tons of FA and about 1.7 million tons of CBA annually (Rafieizonooz, Mirza, Salim, Hussin, \& Khankhaje, 2016) and in Indian around 155 power plants are operated on coal and produces approximately 169.25 million tons of FA and 34 million tons of CBA (CEA, 2017). It was reported by Central Electricity Authority, New Delhi that the fly ash is almost $63.28 \%$ utilized for different purposes i.e., concrete, cement, earth filling, masonry, road embankments, agriculture, and others (CEA, 2017). However, high volume of fly ash is already utilized in the concrete (Hooton, Naik, Ramme, \& Tews, 1994) (Jayaranjan, van Hullebusch, \& Annachhatre, 2014) and it was recognized as a cement constituent and standardized vide BS EN 197-1 (2011). It is also adopted in cement manufacture; to conquer the problem corban dioxide $\left(\mathrm{CO}_{2}\right)$ emissions in the environment. However, the use of CBA is still unexplored, and it is being directly disposed-off in to the open ponds which occupies huge land area and contaminated the soil and underground water resources (IDEM, 2017). According to the Physicians for social responsibility (PSR) (United States Affiliate of International Physicians for the Prevention of Nuclear War, 1985) declared that coal ash has a dangerous and toxic material in storage and disposal under wet condition, but they suggested that dry storage should be for extreme command to avoid leaching, moving or leakage of toxicants. The use coal for the electricity generation has require efforts to manage the safe storage, disposal, and reuse of huge 
amount of coal ash, therefore more research is required to be carried out on the possible use of CBA in concrete construction as to minimize the environmental pollution (Deonarine, Kolker, \& Doughten, 2015). CBA is a porous in nature and dark gray in color and after grinding it poses fine particles as presented in Fig. 1. The chemical characteristics of CBA and fly ash are almost similar, but coarser than fly ash. The CBA particles mostly fall in the range of $4.75 \mathrm{~mm}$ to $90 \mu \mathrm{m}$ (Singh et al., 2015). The particles size of CBA are coarser and almost comparable to that of fine aggregate due to that CBA is formerly considered as sand replacement material in concrete, which causes the reduction in compressive strength of concrete (Singh \& Siddique, 2016). However, after grinding process, it offers good opportunity to be applied as cement, which could deliver better compressive strength (Mangi, Wan Ibrahim, Jamaluddin, Arshad, \& Putra Jaya, 2018a) (Khan \& Ganesh, 2016). But its performance may be affected in the aggressive environment that represents marine environment such as combined condition of suphate and chloride.

Presently, the performance of concrete structure under aggressive conditions is a challenging task for the engineers and solutions for that problem is become more popular. Limited studies have been stated on the concrete with supplementary cementitious material (SCM) under combined effects of sulphate and chloride. Review of literature on the concrete comprising different SCM under sulphate and chloride attacks are summaries in Table 1. 
Table 1

Previous studies

\begin{tabular}{|c|c|c|c|c|c|}
\hline Ref. & Description & $\mathrm{Na}_{2} \mathrm{SO}_{4}$ & $\mathrm{NaCl}$ & $\begin{array}{l}\mathrm{Na}_{2} \mathrm{SO}_{4} \\
+\mathrm{NaCl}\end{array}$ & Key findings \\
\hline $\begin{array}{l}\text { (Maes \& De Belie, } \\
\text { 2014) }\end{array}$ & $\begin{array}{l}\text { Concrete } \\
\text { containing } \\
\text { blast-furnace } \\
\text { slag (BFS) }\end{array}$ & $5 \%$ & $5 \%$ & - & $\begin{array}{l}\text { Chloride penetration } \\
\text { increased as sulphate } \\
\text { content increased. } \\
\text { Sulphate attack is mitigated } \\
\text { by the presence of chloride. }\end{array}$ \\
\hline $\begin{array}{l}\text { (Mangi, Wan } \\
\text { Ibrahim, } \\
\text { Jamaluddin, } \\
\text { Arshad, \& Putra } \\
\text { Jaya, 2018b) }\end{array}$ & $\begin{array}{l}\text { Concrete } \\
\text { containing 10\% } \\
\text { CBA }\end{array}$ & $5 \%$ & $5 \%$ & - & $\begin{array}{l}\text { CBA has substantial } \\
\text { potential to reduce sulphate } \\
\text { and chloride effects in } \\
\text { individual solution }\end{array}$ \\
\hline $\begin{array}{l}\text { (Snelson \& } \\
\text { Kinuthia, 2010) }\end{array}$ & $\begin{array}{l}\text { Mortar } \\
\text { containing } \\
\text { pulverized fuel } \\
\text { ash (PFA) }\end{array}$ & $5 \%$ & - & - & $\begin{array}{l}\text { PFA gives good sulphate } \\
\text { resistance }\end{array}$ \\
\hline $\begin{array}{l}\text { (Sata, } \\
\text { Sathonsaowaphak, } \\
\text { \& Chindaprasirt, } \\
\text { 2012) }\end{array}$ & $\begin{array}{l}\text { Mortar } \\
\text { containing fly } \\
\text { ash and lignite } \\
\text { bottom ash. }\end{array}$ & - & $5 \%$ & - & $\begin{array}{l}\text { Bottom ash mortars deliver } \\
\text { good performance, and it is } \\
\text { less susceptible to sodium } \\
\text { sulphate }\end{array}$ \\
\hline $\begin{array}{l}\text { (Okoye, Prakash, \& } \\
\text { Singh, 2017) }\end{array}$ & $\begin{array}{l}\text { Concrete with } \\
\text { fly ash with } \\
\text { silica fume }\end{array}$ & - & $5 \%$ & - & $\begin{array}{l}\text { Concrete containing silica } \\
\text { fume in sulfuric acid and } \\
\text { chloride solution gives } \\
\text { satisfactory and higher } \\
\text { performance as compared } \\
\text { to control specimen. }\end{array}$ \\
\hline $\begin{array}{l}\text { (Kazi Tani et al., } \\
\text { 2018) }\end{array}$ & $\begin{array}{l}\text { Mortar } \\
\text { incorporated } \\
\text { polyethylene } \\
\text { terephthalate } \\
\text { (PET) }\end{array}$ & $5 \%$ & - & - & $\begin{array}{l}\text { PET blend cement reduces } \\
\text { the effects of } \mathrm{Na}_{2} \mathrm{SO}_{4}\end{array}$ \\
\hline \multirow[t]{3}{*}{$\begin{array}{l}\text { (Stroh, Meng, \& } \\
\text { Emmerling, 2016) }\end{array}$} & \multirow[t]{3}{*}{$\begin{array}{l}\text { Fly ash } \\
\text { concrete with } \\
\text { granulated } \\
\text { blast furnace } \\
\text { slag }\end{array}$} & \multirow[t]{3}{*}{$0.3 \%$} & \multirow[t]{3}{*}{$2 \%$} & \multirow[t]{3}{*}{$1.5 \%$} & $\begin{array}{l}\text { Rapid access and Friedel's } \\
\text { salt formation due to } \\
\text { binding of chloride ions by } \\
\text { alumina. } \\
\text { Ettringite formation due to } \\
\text { sulphate ions. }\end{array}$ \\
\hline & & & & & $\begin{array}{l}\text { Formation of gypsum and } \\
\text { depletion in pH due to } \\
\text { sulphate react with } \\
\text { portlandite. }\end{array}$ \\
\hline & & & & & $\begin{array}{l}\text { Low } \mathrm{pH} \text { leads to depletion in } \\
\text { Friedel's salt. }\end{array}$ \\
\hline
\end{tabular}


Maes \& De Belie, (2014) investigated the sulphate-chloride combined effect on the concrete containing blast-furnace slag as cement. They declared that chloride penetration increased as sulphate content increased but sulphate attack is mitigated by the presence of chloride. Furthermore, Mangi et al., (2018b) investigated individual effects of sodium sulphate and sodium chloride on concrete containing CBA. They were acknowledged that CBA has substantial potential to reduce sulphate and chloride effects in individual solution. Besides that, Snelson \& Kinuthia, (2010) considered pulverized fuel ash (PFA) as cement replacement in the mortar. It was soaking in sodium sulphate solution for 504 days. They found that mortar with PFA gives good sulphate resistance.

Considering the performance of geopolymer mortars containing lignite bottom ash exposed to $3 \%$ sulfuric acid and $5 \%$ sodium sulphate solutions, it was investigated by Sata et al., (2012) that bottom ash mortars delivers good performance and it is less susceptible to sodium sulphate and sulfuric acid solutions. Okoye et al., (2017) evaluated geopolymer concrete containing fly ash and silica fume, exposed to $2 \%$ sulfuric acid and $5 \%$ sodium chloride solutions. Strength was declined around $36 \%$ and $8 \%$ in control mix and concrete with fly ash and silica fume when exposed to $2 \% \mathrm{H}_{2} \mathrm{SO}_{4}$ at 90 days Compressive strengths was declined around $18 \%$ and $0 \%$ in control mix and concrete containing fly ash and silica fume when exposed to $5 \% \mathrm{NaCl}$ at 90 days. Hence, concrete including silica fume in sulfuric acid and chloride solution gives satisfactory and higher performance than the control mix.

Stroh et al., (2016) considered concrete with fly ash and slag exposed to combined attack of sulphate and chloride at laboratory conditions with $\mathrm{NaCl}$ and $\mathrm{Na}_{2} \mathrm{SO}_{4}$ solution different concentration. They declared that rapid access and binding of chloride ions by alumina, causing Friedel's salt formation. However, more sulphate ions encourage to ettringite formation and sulphate react partially with portlandite creating gypsum and pH depletion. Low pH leads to depletion in Friedel's salt. Moreover, Kazi Tani et al., (2018) evaluated influence polyethylene terephthalate (PET) on the concrete performance when exposed to $5 \%$ sodium sulphate $\left(\mathrm{Na}_{2} \mathrm{SO}_{4}\right)$. They declared that PET blend cement reduces the effects of $\mathrm{Na}_{2} \mathrm{SO}_{4}$. Modified concrete / mortars need to be introduced and investigated for the better environment and sustainable development.

The literature review indicated that the earlier studies were conducted on single solution exposure of sulphate or chloride and rare studies were found on combined effects of sulphate and chloride solution. However, the actual conditions are the different than the individual solutions. Most of the real structures are exposed to the collective solutions, especially under marine environment. Therefore, the novel appraisal of this study is to investigate performance of concrete incorporated ground CBA exposed to the combined solution of sulphate and chloride, which solutions represents the marine environment.

\section{Experimental Methodology \\ 2.1. Materials}


Ordinary Portland Cement (OPC) accordance with BS EN 197-1, (2011) having consistency as 30\%, initial setting time 90 minutes, final setting time 270 minutes and specific gravity 3.10 was used. The CBA obtained from a thermal power station, Selangor, Malaysia was used as OPC replacement. Original CBA was grinding for 20 hours in a ball mill grinder as shown in Fig. 2. The chemical characteristics of OPC and CBA was assessed through X-Ray fluorescence (XRF) test refer Table 2. However, it was found that the $\mathrm{CBA}$ is rich in $\mathrm{SiO}_{2}, \mathrm{Al}_{2} \mathrm{O}_{3}, \mathrm{Fe}_{2} \mathrm{O}_{3}$ and its collective sum is around $78.4 \%$ which is greater than $70 \%$. Hence, CBA is characterized as Class F ash with reference to ASTM C618 standard (ASTM C618-05, 2005). In addition to that, the particle size of OPC and CBA was also evaluated through Particle Size Analyzer (PSA) and results are provided in Fig. 3. It was observed through the PSA that OPC is finer than ground CBA. The OPC particles were fall in the range of $3.8 \mu \mathrm{m}$ to $21.2 \mu \mathrm{m}$, whereas CBA particles were in the range of $3.7 \mu \mathrm{m}$ to $50.5 \mu \mathrm{m}$. However, the specific gravity of OPC and CBA were recorded as 3.10 and 2.41, respectively. Additionally, Scanning Electron Microscope (SEM) of CBA is also provided in Figure. 4, which shows CBA particle shapes, indicated as irregular, sharp and spherical particles.

Table 2

Physical and chemical characteristics of OPC and CBA

\begin{tabular}{|lll|}
\hline Content (\%) & O.P.C & C.B.A \\
\hline $\mathrm{SiO}_{2}$ & 20.6 & 52.5 \\
\hline $\mathrm{Al}_{2} \mathrm{O}_{3}$ & 3.9 & 17.6 \\
\hline $\mathrm{Fe}_{2} \mathrm{O}_{3}$ & 3.5 & 8.3 \\
\hline $\mathrm{CaO}$ & 63.9 & 4.7 \\
\hline $\mathrm{TiO}_{2}$ & 0.2 & 2.2 \\
\hline $\mathrm{K}_{2} \mathrm{O}$ & - & 0.8 \\
\hline $\mathrm{MgO}$ & 1.9 & 0.6 \\
\hline $\mathrm{SrO}$ & - & 0.2 \\
\hline $\mathrm{P}_{2} \mathrm{O}_{5}$ & - & 0.3 \\
\hline SO & & 0.8 \\
\hline Loss on ignition $(\mathrm{LOI})$ & 2.2 & 4.0 \\
\hline Sp. gravity & 3.1 & 2.4 \\
\hline Sp. surface area $\left(\mathrm{cm}{ }^{2} / \mathrm{g}\right)$ & 4871 & 3836 \\
\hline Size of particles $(\mu \mathrm{m})$ & min 0.04, max 71 & min 0.04, max 170 \\
\hline
\end{tabular}

\subsection{Concrete mix}


The scope of this study is to involve $10 \%$ CBA as SCM, it was also formerly recommended as an optimum proportion in concrete production (Mangi et al., 2018a) (Mangi et al., 2019). Therefore, two concrete mixes were prepared with a fixed water to binder ratio $(\mathrm{w} / \mathrm{b})$ 0.5. First mix containing $100 \%$ OPC and second mix were incorporated $10 \%$ CBA as SCM. Fine aggregates passing from $5 \mathrm{~mm}$ sieve, coarse aggregates nominal maximum size of $10 \mathrm{~mm}$ was used in this study. The $\mathrm{ACl}$ method was used to prepare concrete mix proportions as shown in Table 3.

Table 3

Concrete mix details $\mathrm{kg} / \mathrm{m}^{3}$

\begin{tabular}{|c|c|c|}
\hline \multirow[t]{2}{*}{ Ingredients } & Control mix concrete & Concrete incorporated CBA \\
\hline & M1 & M2 \\
\hline Cement & 440.0 & 396.0 \\
\hline CBA & 0.00 & 44.0 \\
\hline Fine aggregates & 805.0 & 805.0 \\
\hline Coarse aggregates & 828.0 & 828.0 \\
\hline Water & 220.0 & 220.0 \\
\hline
\end{tabular}

\subsection{Scope of study}

This study evaluated performance of concrete incorporated CBA under sulphate-chloride conditions. Three groups of specimens were prepared as shown in Table 4. Group-I specimens; initially kept in normal water for 28 days to achieve targeted compressive strength 35MPa. Afterward, specimens were transferred into $5 \% \mathrm{Na}_{2} \mathrm{SO}_{4}+5 \% \mathrm{NaCl}$ solution and compressive strength test were performed at 28,56 , 90 and 180 days. Next, Group-II specimens; were cured in normal water and RCPT testing were performed at 28 and 180 days. Group-III specimens; initially cured in normal water for 7 days as per ASTM C596 (ASTM C596, 2010), afterward specimens were kept at the room ambient temperature and drying shrinkage readings were takes at $1,3,7,14,28,56,90$ and 180 days. Figure 5 shows the experimental setup for compressive strength, RCPT instrument and drying shrinkage instrument. 
Table 4

Specimens prepared for the study.

\begin{tabular}{|llll|}
\hline Group & Shape and Dimensions & Purpose & Quantity \\
\hline I & $\begin{array}{l}\text { Concrete Cubes } \\
\text { Length } 100 \mathrm{~mm} \text {, width } 100 \text { and depth } 100 \\
\text { mm }\end{array}$ & Compressive strength test & 30 \\
\hline II & $\begin{array}{l}\text { Concrete cylinders } \\
\text { Diameter } 100 \mathrm{~mm} \text {, length } 200 \mathrm{~mm}\end{array}$ & $\begin{array}{l}\text { Rapid chloride permeability } \\
\text { test }\end{array}$ & 6 \\
\hline III & $\begin{array}{l}\text { Concrete prisms } \\
\text { Cross-Sect. } 100 \mathrm{~mm} \text {, length } 300 \mathrm{~mm}\end{array}$ & Drying shrinkage & 6 \\
\hline
\end{tabular}

\section{Results And Discussion}

\subsection{Compressive strength performance}

To evaluate the pozzolanic reaction of CBA in concrete, the specimens were prepared with $10 \%$ CBA as a replacement of OPC. Moreover, specimens were cured in normal water and combined solution of $5 \%$ sodium sulphate $\left(\mathrm{Na}_{2} \mathrm{SO}_{4}\right)$ and $5 \%$ sodium chloride $(\mathrm{NaCl})$. Experimental results are summaries in Table 5 and Fig. 6, demonstrated the compressive strength relationship with respect to exposure period concrete, while Fig. 7, indicated the percentage variation in compressive strength under normal water and combined solution of $5 \% \mathrm{Na}_{2} \mathrm{SO}_{4}+5 \% \mathrm{NaCl}$.

It was observed that performance of $\mathrm{M} 2$ under normal water was found to be superior to M1. At the early days, the compressive strength of $M 2$ was lower than $M 1$, because pozzolanic reaction yet not initiated, then at 56 day and onwards, compressive strength of M2 was noticed greater than M1. It was noticed that the hydration process is affected due to $\mathrm{CBA}$ in concrete due to reduction in the amount of $\mathrm{Ca}(\mathrm{OH})_{2}$ (Jaturapitakkul \& Cheerarot, 2003). However, M2 concrete which contained $10 \%$ ground CBA cured in normal water gives the compressive strength $60.0 \mathrm{MPa}$ at 180 days, which is almost $12 \%$ greater than the control mix (M1) concrete. While same concrete gives $0.2 \%$ higher compressive strength when exposed to combined solution of $5 \% \mathrm{Na}_{2} \mathrm{SO}_{4}+5 \% \mathrm{NaCl}$ at 180 days. It was observed that $\mathrm{M} 1$ concrete when exposed to combined $5 \% \mathrm{Na}_{2} \mathrm{SO}_{4}+5 \% \mathrm{NaCl}$ solution, reduces its strength from $44 \mathrm{MPa}$ to $40.6 \mathrm{MPa}$ at the age of 28 days and $55.3 \mathrm{MPa}$ to $51.05 \mathrm{MPa}$ at the 90 days, this is due to reduction in binding ability in presence of sulphate-chloride condition. Previously, it was explained that the binding of incoming sulphate ions consequences in the formation of ettringite and gypsum (De Weerdt \& Justnes, 2015). Formation of Ettringite in first phase until bonding capacity of alumina is depleted according to below principal (Stroh et al., 2016) Eq. (1): 
$\left[\mathbf{C a}_{3} \mathbf{A l}(\mathbf{O H})_{6} \cdot 12 \mathbf{H}_{2} \mathbf{O}\right]_{2}^{3+}+3 \mathbf{S O}_{4}^{2-} \rightarrow\left[\mathbf{C a}_{3} \mathbf{A l}(\mathbf{O H})_{6} \cdot 12 \mathbf{H}_{2} \mathbf{O}\right]_{2}$.

$\left(\mathrm{SO}_{4}\right)_{3} \cdot 2 \mathrm{H}_{2} \mathbf{O} \cdot 3 \mathrm{CaO} \cdot \mathrm{Al}_{2} \mathrm{O}_{3} \cdot 3 \mathrm{CaSO}_{4} \cdot 32 \mathrm{H}_{2} \mathrm{O}$

It was also observed in this study that control mix (M1) concrete, when exposed to combined solution of $5 \% \mathrm{Na}_{2} \mathrm{SO}_{4}+5 \% \mathrm{NaCl}$, losses its binding ability. Whereas $\mathrm{M} 2$ concrete which containing $10 \% \mathrm{CBA}$, enhances the silica and alumina content in the cement paste and resulting in the development of compressive strength.

Table 5

Compressive strength and percentage variation in compressive strength

\begin{tabular}{|lllll|}
\hline Exposure period (days) & \multicolumn{2}{l}{ Exposed to normal water } & \multicolumn{2}{l|}{ Exposed to $5 \% \mathrm{Na}_{2} \mathrm{SO}_{4}+5 \% \mathrm{NaCl}$} \\
\cline { 2 - 5 } & $\begin{array}{l}\mathrm{M} 1 \\
(\mathrm{MPa})\end{array}$ & $\begin{array}{l}\mathrm{M} 2 \\
(\mathrm{MPa})\end{array}$ & $\begin{array}{l}\mathrm{M} 1 \\
(\mathrm{MPa})\end{array}$ & $\begin{array}{l}\text { M2 } \\
(\mathrm{MPa})\end{array}$ \\
\hline 28 & 46.8 & 43.5 & 44.0 & 40.6 \\
\hline 56 & 50.8 & 53.2 & 51.9 & 51.7 \\
\hline 90 & 52.1 & 58.00 & 55.3 & 51.05 \\
\hline 180 & 53.6 & 60.00 & 52.7 & 52.8 \\
\hline
\end{tabular}

3.2 Micrograph and X-ray diffraction (XRD) Analysis

Scanning Electron Microscopy (SEM) and X-ray diffraction (XRD) technique were adopted to analyse the problems associated to the concrete when it was exposed to the combined sulphate-chloride at 180 days. Figure 8 shows the condition of control mix (M1) concrete exposed to combined solution of $5 \% \mathrm{Na}_{2} \mathrm{SO}_{4}$ and $5 \% \mathrm{NaCl}$. Whereas Fig. 9 shows the condition of concrete with $10 \%$ CBA (M2) exposed to combined solution of $5 \% \mathrm{Na}_{2} \mathrm{SO}_{4}$ and $5 \% \mathrm{NaCl}$. Micrograph of $\mathrm{M} 1$ and $\mathrm{M} 2$ concrete indicated two major features. One is the holding salts and second is the formation of $\mathrm{C}-\mathrm{S}-\mathrm{H}$ gel. The reduction in concrete strength is mainly caused by less formation of C-S-H gel (Aggarwal \& Siddique, 2014). The formation of C-S-H gel is retarded due to salt of sulphate and chloride. It was observed that concrete with CBA (M2) has well formation of C-S-H gel as compared to normal concrete (M1).

Furthermore, it was observed that the amount of calcium silicate was found higher in control mix (CM) as compared to concrete containing CBA. The presence of CBA in concrete produces more C-S-H gel. Since CBA is high in aluminium and OPC paste is high in calcium carbonate, which makes reaction among these two compounds and form tricalcium aluminate $\left(\mathrm{C}_{3} \mathrm{~A}\right)$ and gives the adequate strength development. However, the development of ettringites (hydrous calcium aluminium sulphate) formation gives the good strength as the volume of voids were occupied by the ettringites (Aggarwal \& Siddique, 2014). Moreover, the $\mathrm{CM}$ exposed to combined solution of $5 \% \mathrm{Na}_{2} \mathrm{SO}_{4}+5 \% \mathrm{NaCl}$ was found to be more sever. Because the presence of $\mathrm{NaCl}$ salts produces chloro-aluminate in chloride solutions and 
deterioration takes place by de-calcifications, that was noticed in all specimens. It was noticed that the hydration of cement formed different products such as quartz $\left(\mathrm{SiO}_{2}\right)$, portlandite (calcium hydroxide), belite $\left(\mathrm{C}_{2} \mathrm{~S}\right)$, alite $\left(\mathrm{C}_{3} \mathrm{~S}\right)$, calcium silicate hydrate $(\mathrm{CSH}), \mathrm{C}_{3} \mathrm{~A}$ (tricalcium aluminate) and ettringite $\left(\mathrm{C}_{3} \mathrm{~A}\right.$ $\left.(\mathrm{CS}) \mathrm{H}_{32}\right)$. The pozzolanic reaction was detected in the concrete containing $\mathrm{CBA}$, reaction among $\mathrm{Ca}(\mathrm{OH})_{2}$ (calcium-hydroxide). It shows that CBA could create well shape CSH gel which delivered higher compressive strength performances.

\subsection{Chloride penetration performance}

The durability of concrete can be assessed through Rapid Chloride Penetration Test (RCPT). It is necessary to check chloride penetrability when concrete structure is built within the chloride environment. In this study, involves CBA as Supplementary Cementitious Material in concrete. However, CBA contains $17.65 \%$ aluminium oxide $\left(\mathrm{Al}_{2} \mathrm{O}_{3}\right)$ and OPC contains $3.95 \%$, which means that concrete containing $\mathrm{CBA}$ (M2) holds more amount of $\mathrm{Al}_{2} \mathrm{O}_{3}$. Therefore, chlorides physically and chemically bound due to adsorption on the surface of hydrates $\mathrm{C}-\mathrm{S}-\mathrm{H}$ and $\mathrm{C}-\mathrm{A}-\mathrm{H}$. Addition of $\mathrm{CBA}$, increases the amount of $\mathrm{Al}_{2} \mathrm{O}_{3}$, which gives the better chloride binding ability (Argiz, Moragues, \& Menéndez, 2018). Besides that, fine particle of CBA also fills the free pore (Argiz, Sanjuán, \& Menéndez, 2017). These phenomenal change gives the lower penetration of chloride ions through the concrete incorporated $10 \%$ CBA. It was observed that concrete with $10 \% \mathrm{CBA}(\mathrm{M} 2)$ gives the lower chloride penetration as the age of concrete increased. It was observed from the Fig. 10, that the control mix (M1) concrete gives higher values than the high category as per ASTM C1202 (ASTM.C1202, 2006) whereas, M2 concrete gives around $33.6 \%$ lower chloride penetration than the M1 at the age of 180 days.

\subsection{Drying shrinkage performance}

This study evaluated the effect of CBA on the drying shrinkage (DS) of concrete was also evaluated. However, it was previously noticed that the shrinkage occurred in first two months and for later age, very less variation in shrinkage of concrete (Saha, 2018). It was experimentally known that the DS in the control mix (M1) is higher than the concrete containing 10\% CBA (M2) even up to 180 days as shown in Fig. 11. The DS is significantly depending on the fineness of supplementary cementing materials (SCM), it was formerly noticed that concrete containing fly ash nano-particle, gives the higher DS (Gao, He, Li, Tang, \& Qu, 2017) and DS decreases when the coarser fly ash was used (Saha, 2018). The DS in concrete containing 10\%CBA (M2) were noticed lower than control mix (M1), which validated that ground CBA particle are coarser than the Ordinary Portland Cement (OPC). However, CBA addition as SCM, reduces the $\mathrm{CaO}$ contained in the cement paste which leading towards reduction in hydration process. Thus, lower DS was recorded in $\mathrm{M} 2$ as compared to $\mathrm{M} 1$.

\section{Conclusions}


This study declared CBA as supplementary cementitious material (SCM) due to presence of substantial proportion of three main oxidise i.e. silica, alumina and ferrous. Following conclusions can be drawn.

i. Concrete incorporated $10 \%$ CBA gives $12 \%$ higher compressive strength than normal concrete cured in normal water. Once it was exposed to combined solution of sulphate-chloride is gives around $0.2 \%$ higher compressive strength as compared to normal concrete.

ii. It was detected through micrographs that concrete containing CBA has well formation of C-S-H gel as compared to the control mix concrete. However, the development in the strength was noticed.

iii. Incorporation of $10 \%$ CBA in concrete reduces the chloride penetration around $33.6 \%$ at the age of 180 days. It indicated that CBA could be utilized in concrete to enhance the durability performance of concrete.

iv. Concrete containing $10 \%$ CBA exhibits around $29.2 \%$ lower drying shrinkage as compared to the normal concrete at the age of 180 days.

It was observed that the replacement of cement with CBA offers the technical and environmental advantages, which are considered as important aspects in the sustainable concrete construction. However, this study considered samples under submerged conditions and future studies could be considered wetting and drying conditions.

\section{Declarations}

\section{Funding Statement}

Universiti Tun Hussein Onn Malaysia and Ministry of Education Malaysia through the Fundamental Research Grant Scheme (FRGS) Vot No. FRGS/1/2018/TK01/UTHM/02/3.

\section{Authors Contributions}

Sajjad Ali Mangi: Preparation of original draft, experimental performance, analysis.

Mohd Haziman Wan Ibrahim: Supervision, methodology.

Norwati Jamaluddin: Review and Proof reading

Mohd Fadzil Arshad: Review

Shabir Hussain Khahro: Review and Editing

Ramadhansyah Putra Jaya: Review

\section{Availability of data and Material}

Locally available materials were used in this study. 


\section{Compliance with ethical standards}

All ethical standards have been fallowed during this research.

\section{Consent to participate.}

Not Applicable

\section{Consent to Publish.}

Not Applicable

\section{Acknowledgement}

This study was supported by Universiti Tun Hussein Onn Malaysia and Ministry of Education Malaysia through the Fundamental Research Grant Scheme (FRGS) Vot No. FRGS/1/2018/TK01/UTHM/02/3. The writers also gratefully acknowledge the support of Mehran University of Engineering and Technology, Pakistan.

\section{Conflict of Interest}

On behalf of all authors, the corresponding author states that there is no conflict of interest.

\section{References}

1. ACAA. (2017). American Coal Ash Association Production and Use News Release. American Coal Ash Association, 1-4.

2. Aggarwal, Y., \& Siddique, R. (2014). Microstructure and properties of concrete using bottom ash and waste foundry sand as partial replacement of fine aggregates. Construction and Building Materials, 54, 210-223. https://doi.org/10.1016/j.conbuildmat.2013.12.051

3. Argiz, C., Moragues, A., \& Menéndez, E. (2018). Use of ground coal bottom ash as cement constituent in concretes exposed to chloride environments. Journal of Cleaner Production, 170, 25-33. https://doi.org/10.1016/j.jclepro.2017.09.117

4. Argiz, C., Sanjuán, M. Á., \& Menéndez, E. (2017). Coal Bottom Ash for Portland Cement Production. Advances in Materials Science and Engineering. https://doi.org/10.1155/2017/6068286

5. Asokan, P., Saxena, M., \& Asolekar, S. R. (2005). Coal combustion residues-environmental implications and recycling potentials. Resources, Conservation and Recycling, 43(3), 239-262. https://doi.org/10.1016/j.resconrec.2004.06.003

6. ASTM.C1202. (2006). Understanding AASHTO T277 and ASTM C1202 Rapid Chloride Permeability Test. GRACE Construction.

7. ASTM C596. (2010). Standard Test Method for Drying Shrinkage of Mortar Containing Hydraulic Cement 1. Annual Book of ASTM Standards, 11(5), 11-13. https://doi.org/10.1520/C0596-09.2 
8. ASTM C618-05. (2005). Standard Specification for Coal Fly Ash and Raw or Calcined Natural Pozzolan for Use. Annual Book of ASTM Standards, 3-6. https://doi.org/10.1520/C0618

9. BS EN 197-1. (2011). Cement Part 1: Composition, Specifications and Conformity Criteria for Common Cements. British Standard, 50. https://doi.org/doi:10.3403/30205527U

10. CEA. (2017). Report on Fly Ash Generation at Coal/Lignite Based Thermal Power Stations and its Utilization in the Country for the year 2016-17, (December), 1-63. https://doi.org/http://www.cea.nic.in/reports/others/thermal/tcd/flyash_201617.pdf

11. De Weerdt, K., \& Justnes, H. (2015). The effect of sea water on the phase assemblage of hydrated cement paste. Cement and Concrete Composites, 55, 215-222.

https://doi.org/10.1016/j.cemconcomp.2014.09.006

12. Deonarine, A., Kolker, A., \& Doughten, M. (2015). Trace Elements in Coal Ash. U.S. Geological Survey. USGS. https://doi.org/10.1016/B978-0-408-03309-1.50002-2

13. Gao, Y., He, B., Li, Y., Tang, J., \& Qu, L. (2017). Effects of nano-particles on improvement in wear resistance and drying shrinkage of road fly ash concrete. Construction and Building Materials, 151, 228-235. https://doi.org/10.1016/j.conbuildmat.2017.06.080

14. Hooton, R., Naik, T., Ramme, B., \& Tews, J. (1994). Use of High Volumes of Class C and Class F Fly Ash in Concrete. Cement, Concrete and Aggregates, 16(1), 12. https://doi.org/10.1520/CCA10556J

15. Hui, K. S., Hui, K. N., \& Lee, S. K. (2009). A novel and green approach to produce nano-porous materials zeolite $A$ and $\mathrm{MCM}-41$ from coal fly ash and their applications in environmental protection. International Journal of Chemical and Biomolecular Engineering, 2(4), 165-175.

16. IDEM. (2017). Coal Combustion Residuals (Coal Ash).

17. Jaturapitakkul, C., \& Cheerarot, R. (2003). Development of Bottom Ash as Pozzolanic Material. JOURNAL OF MATERIALS IN CIVIL ENGINEERING, 15(February), 48-53.

18. Jayaranjan, M. L. D., van Hullebusch, E. D., \& Annachhatre, A. P. (2014). Reuse options for coal fired power plant bottom ash and fly ash. Reviews in Environmental Science and Bio/Technology, 13(4), 467-486. https://doi.org/10.1007/s11157-014-9336-4

19. Kazi Tani, N., Benosman, A. S., Senhadji, Y., Taïbi, H., Mouli, M., \& Belbachir, M. (2018). Prediction models of mechanical properties for pet-mortar composite in sodium sulphateaggressive mediums. MATEC Web of Conferences, 149, 01051. https://doi.org/10.1051/matecconf/201714901051

20. Khan, R. A., \& Ganesh, A. (2016). The effect of coal bottom ash (CBA) on mechanical and durability characteristics of concrete. Journal of Building Materials and Structures, (3), 31-42.

21. Maes, M., \& De Belie, N. (2014). Resistance of concrete and mortar against combined attack of chloride and sodium sulphate. Cement and Concrete Composites, 53, 59-72. https://doi.org/10.1016/j.cemconcomp.2014.06.013

22. Mangi, S. A., Wan Ibrahim, M. H., Jamaluddin, N., Arshad, M. F., \& Putra Jaya, R. (2018a). Effects of Ground Coal Bottom Ash on the Properties of Concrete. Journal of Engineering Science and Technology Vol., 14(1), 338-350. 
23. Mangi, S. A., Wan Ibrahim, M. H., Jamaluddin, N., Arshad, M. F., \& Putra Jaya, R. (2018b). Short-term effects of sulphate and chloride on the concrete containing coal bottom ash as supplementary cementitious material. Engineering Science and Technology, an International Journal. https://doi.org/10.1016/j.jestch.2018.09.001

24. Mangi, S. A., Wan Ibrahim, M. H., Jamaluddin, N., Shahidan, S., Arshad, M. F., Memon, S. A., ... Setiawan, M. I. (2019). Influence of Ground Coal Bottom Ash on the Properties of Concrete. International Journal of Sustainable Construction Engineering and Technology, 9(2), 26-34. https://doi.org/10.30880/ijscet.2018.09.02.003

25. Okoye, F. N., Prakash, S., \& Singh, N. B. (2017). Durability of fly ash based geopolymer concrete in the presence of silica fume. Journal of Cleaner Production, 149, 1062-1067. https://doi.org/10.1016/j.jclepro.2017.02.176

26. Rafieizonooz, M., Mirza, J., Salim, M. R., Hussin, M. W., \& Khankhaje, E. (2016). Investigation of coal bottom ash and fly ash in concrete as replacement for sand and cement. Construction and Building Materials, 116, 15-24. https://doi.org/10.1016/j.conbuildmat.2016.04.080

27. Saha, A. K. (2018). Effect of class F fly ash on the durability properties of concrete. Sustainable Environment Research, 28(1), 25-31. https://doi.org/10.1016/j.serj.2017.09.001

28. Sata, V., Sathonsaowaphak, A., \& Chindaprasirt, P. (2012). Resistance of lignite bottom ash geopolymer mortar to sulfate and sulfuric acid attack. Cement and Concrete Composites, 34(5), 700-708. https://doi.org/10.1016/j.cemconcomp.2012.01.010

29. Singh, M., \& Siddique, R. (2016). Effect of coal bottom ash as partial replacement of sand on workability and strength properties of concrete. Journal of Cleaner Production, 112, 620-630. https://doi.org/10.1016/j.jclepro.2015.08.001

30. Singh, M., Siddique, R., Ait-Mokhtar, K., \& Belarbi, R. (2015). Durability Properties of Concrete Made with High Volumes of Low-Calcium Coal Bottom Ash As a Replacement of Two Types of Sand. Journal of Materials in Civil Engineering, 28(2009), 04015175. https://doi.org/10.1061/(ASCE)MT.1943-5533.0001464

31. Snelson, D. G., \& Kinuthia, J. M. (2010). Resistance of mortar containing unprocessed pulverised fuel ash (PFA) to sulphate attack. Cement and Concrete Composites, 32(7), 523-531. https://doi.org/10.1016/j.cemconcomp.2010.03.001

32. Stroh, J., Meng, B., \& Emmerling, F. (2016). Deterioration of hardened cement paste under combined sulphate-chloride attack investigated by synchrotron XRD. Solid State Sciences. https://doi.org/10.1016/j.solidstatesciences.2016.04.002

33. United States Affiliate of International Physicians for the Prevention of Nuclear War. (1985). Coal Ash: Hazardous to Human Health. Physicians for Social Responsibility.

\section{Figures}



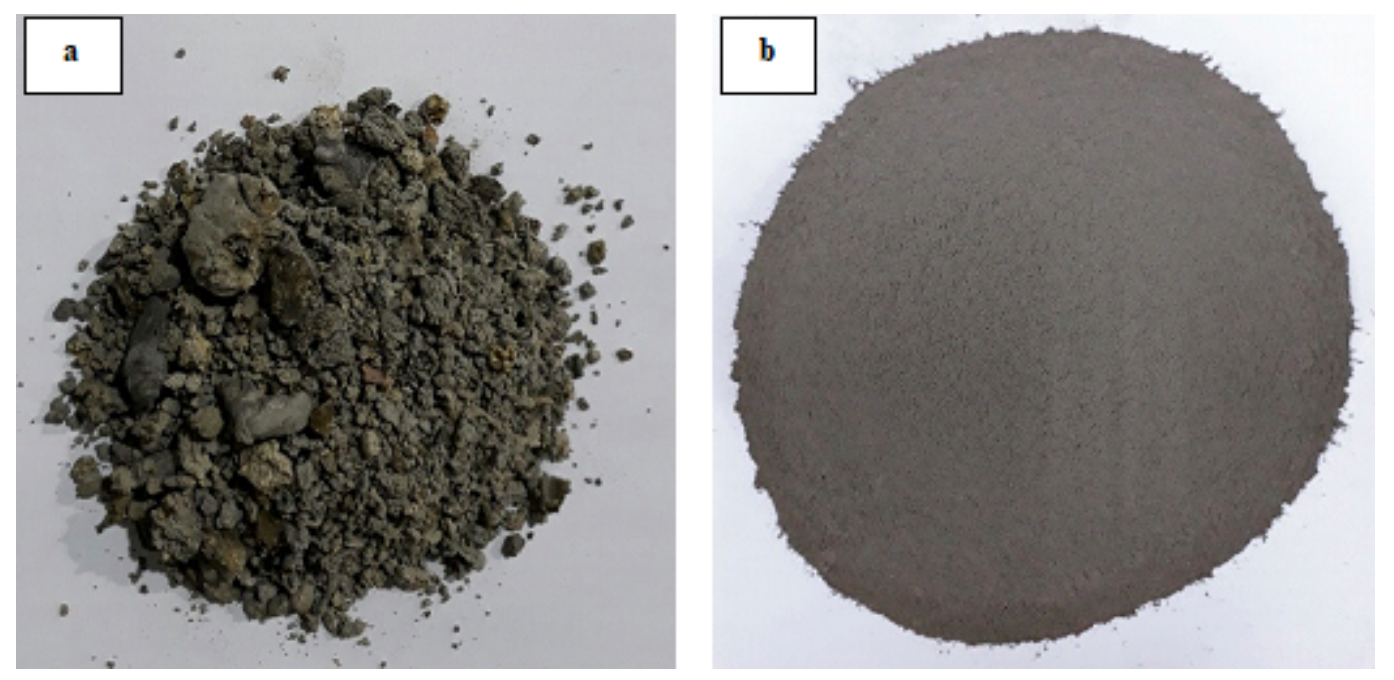

Figure 1

a) Original $\mathrm{CBA}, \mathrm{b}$ ) Ground $\mathrm{CBA}$

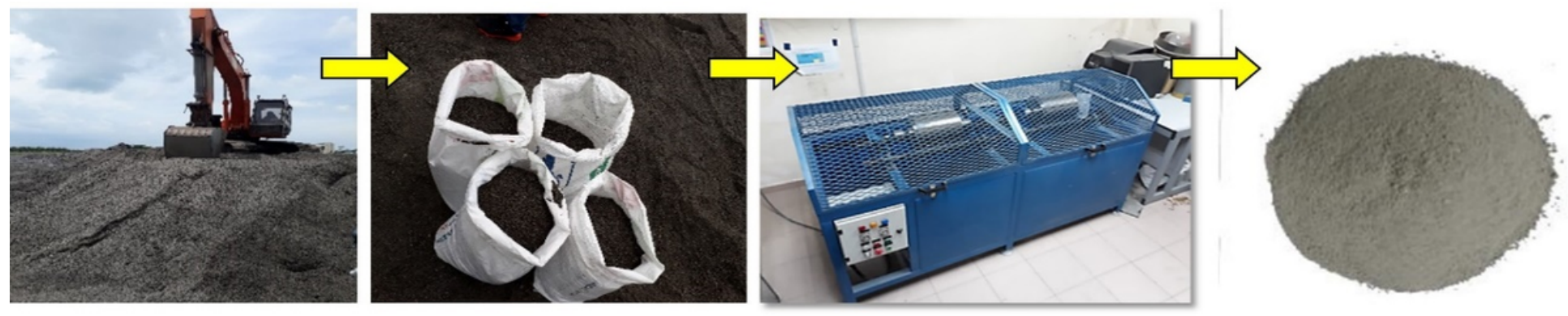

Figure 2

Grinding process for the preparation of CBA 


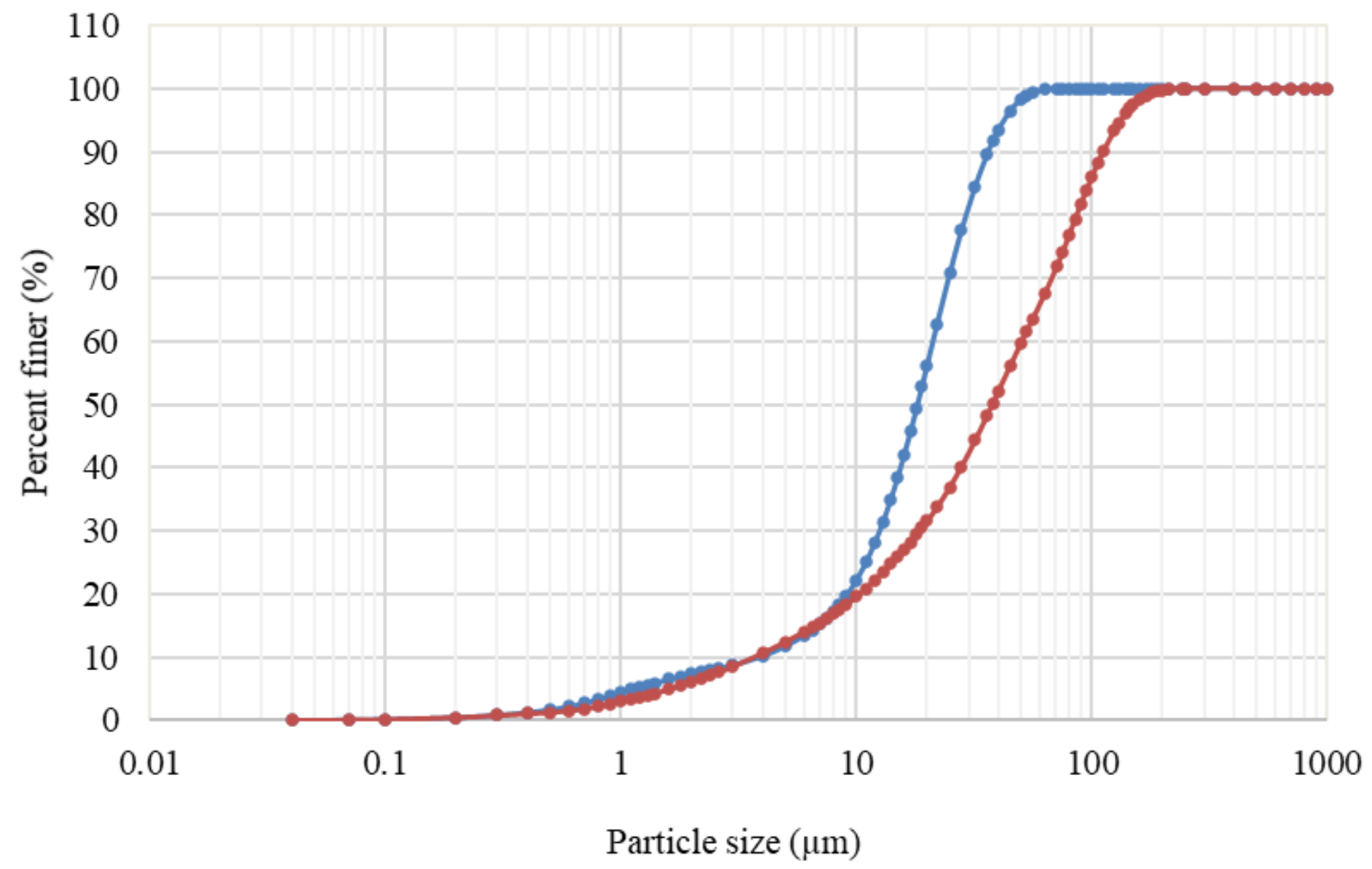

Figure 3

Particle size of OPC and CBA 


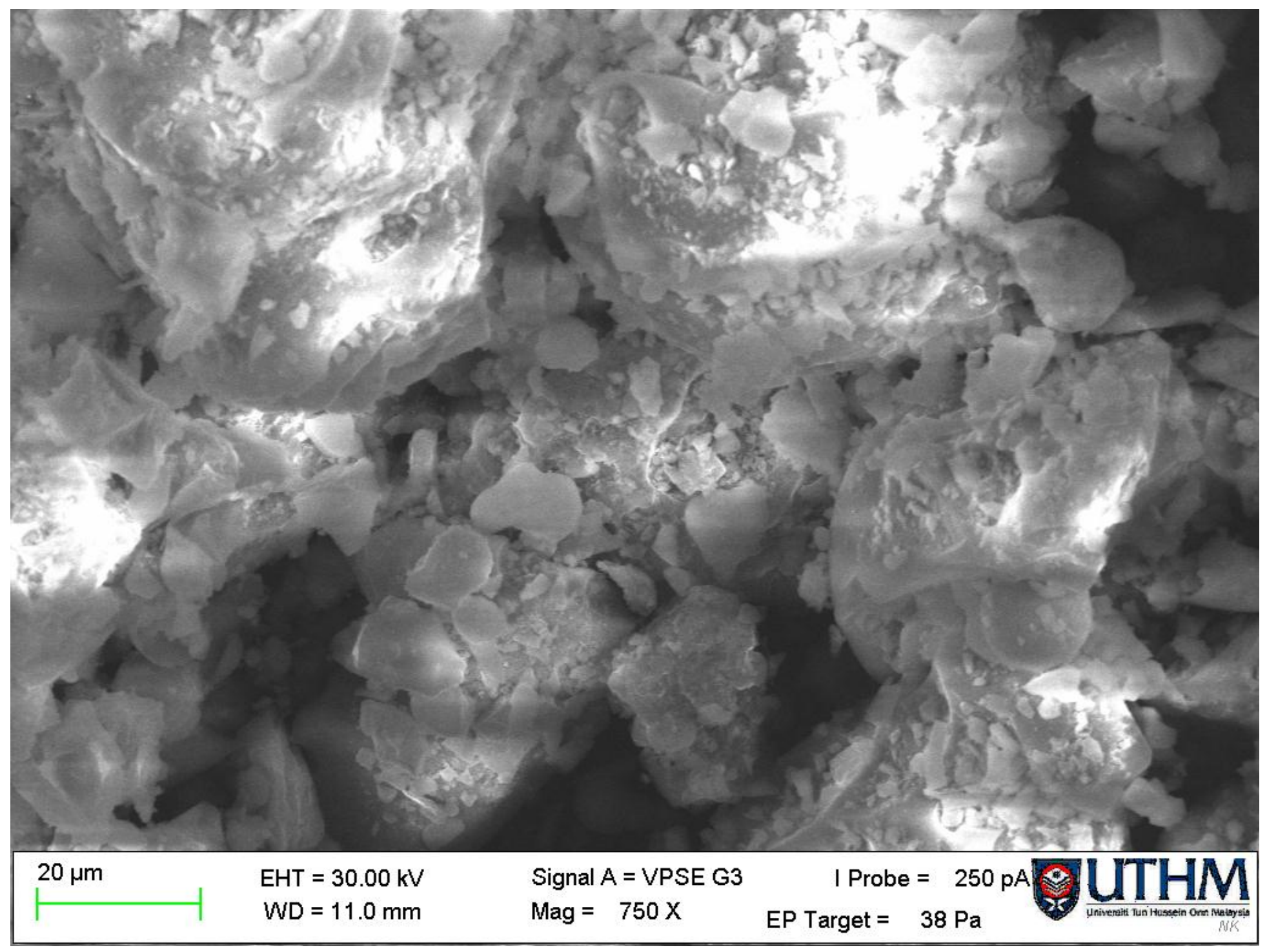

Figure 4

SEM image of coal bottom ash
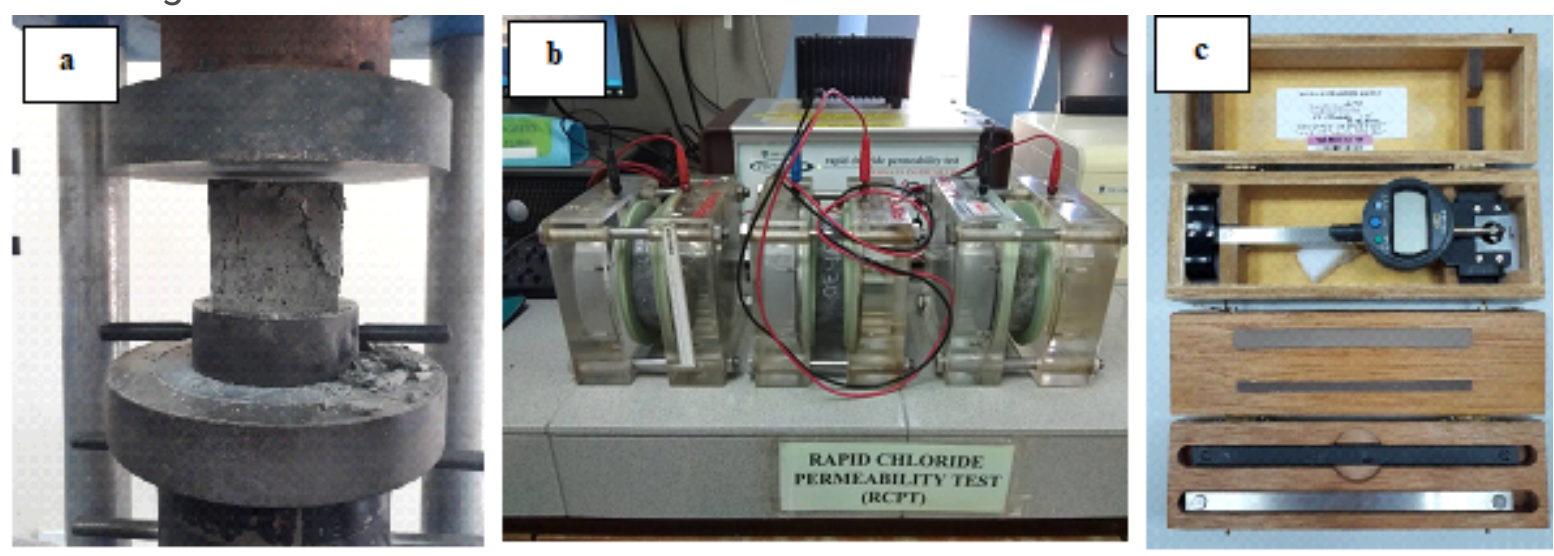

Figure 5

Experimental set-put, a) Compressive test, b) RCPT instrument, c) Drying shrinkage instrument 


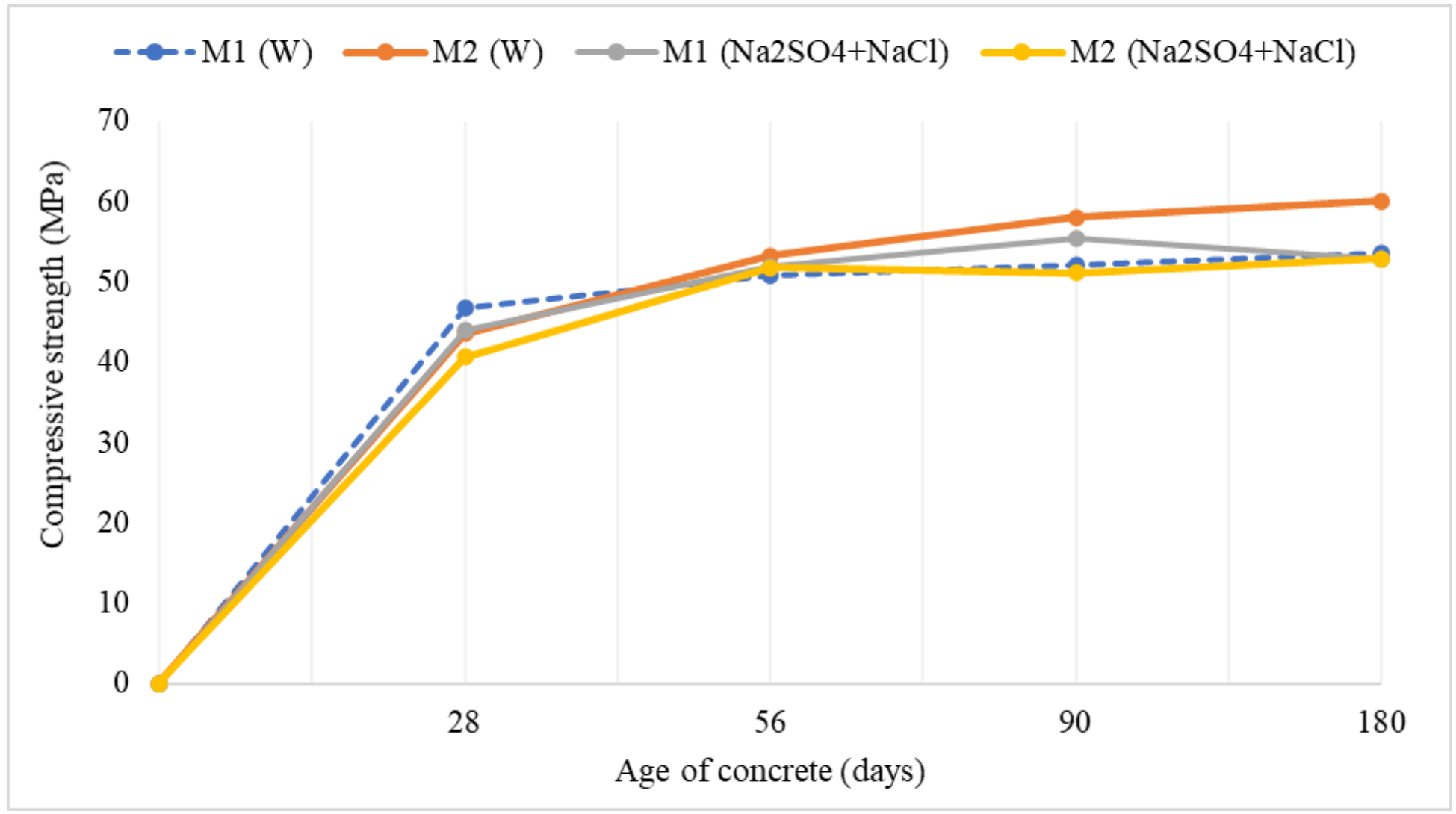

Figure 6

Compressive strength performance of concrete with and without CBA

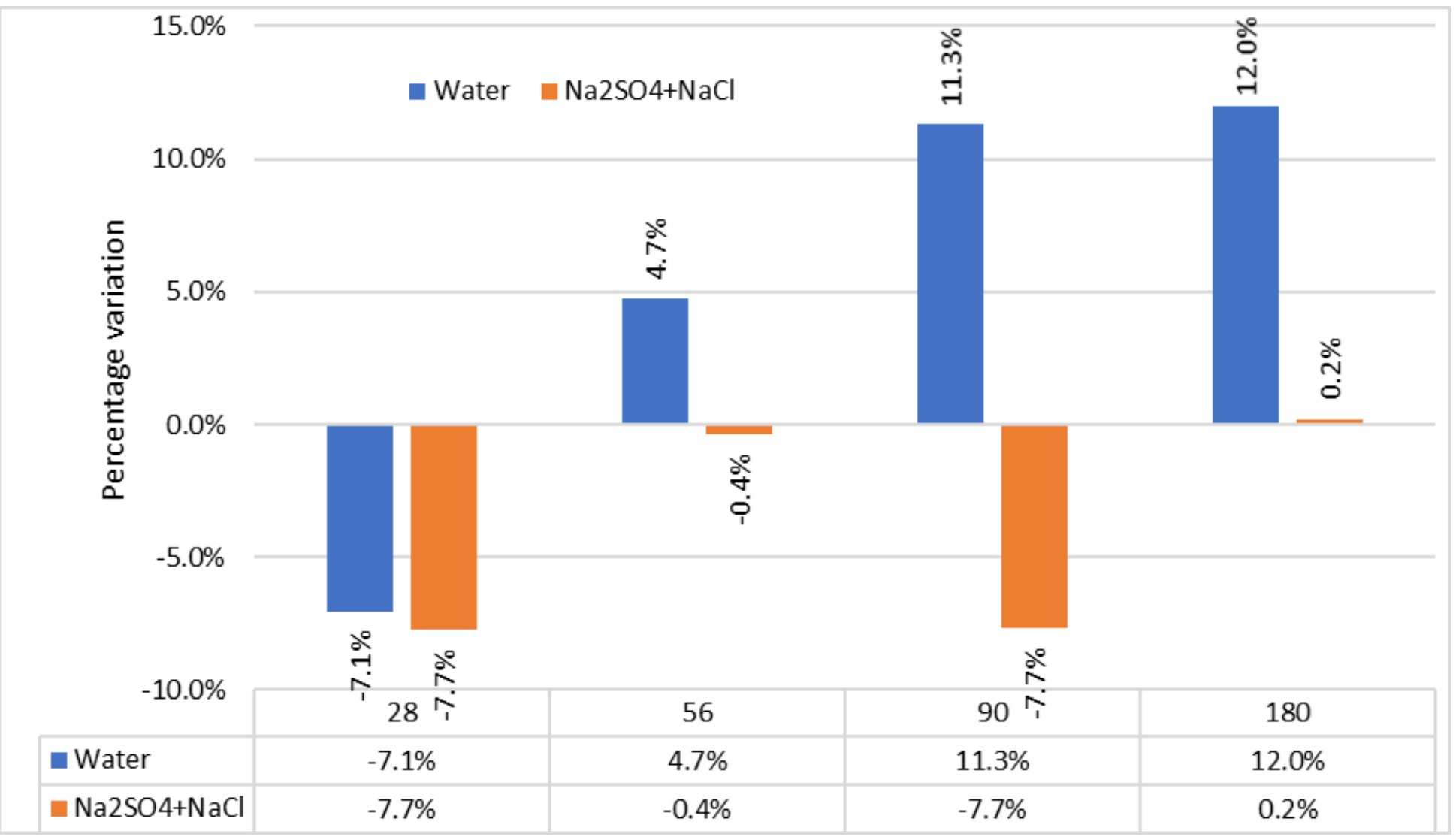


Figure 7

Compressive strength percentage variation of $\mathrm{M} 2$ as compared to $\mathrm{M} 1$

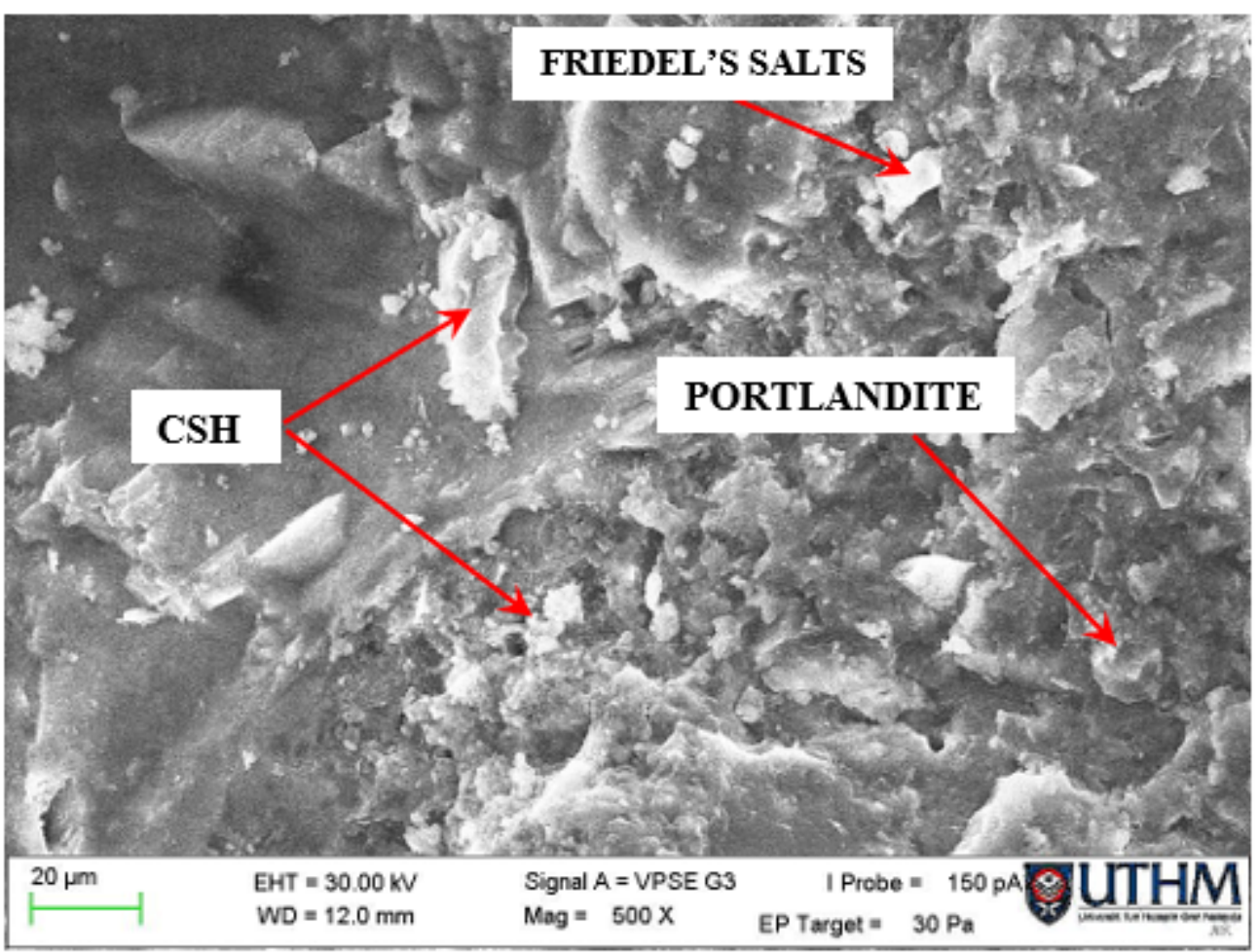

Figure 8

SEM image of the concrete without CBA exposed to combined solution of $\mathrm{Na} 2 \mathrm{SO} 4+\mathrm{NaCl}$

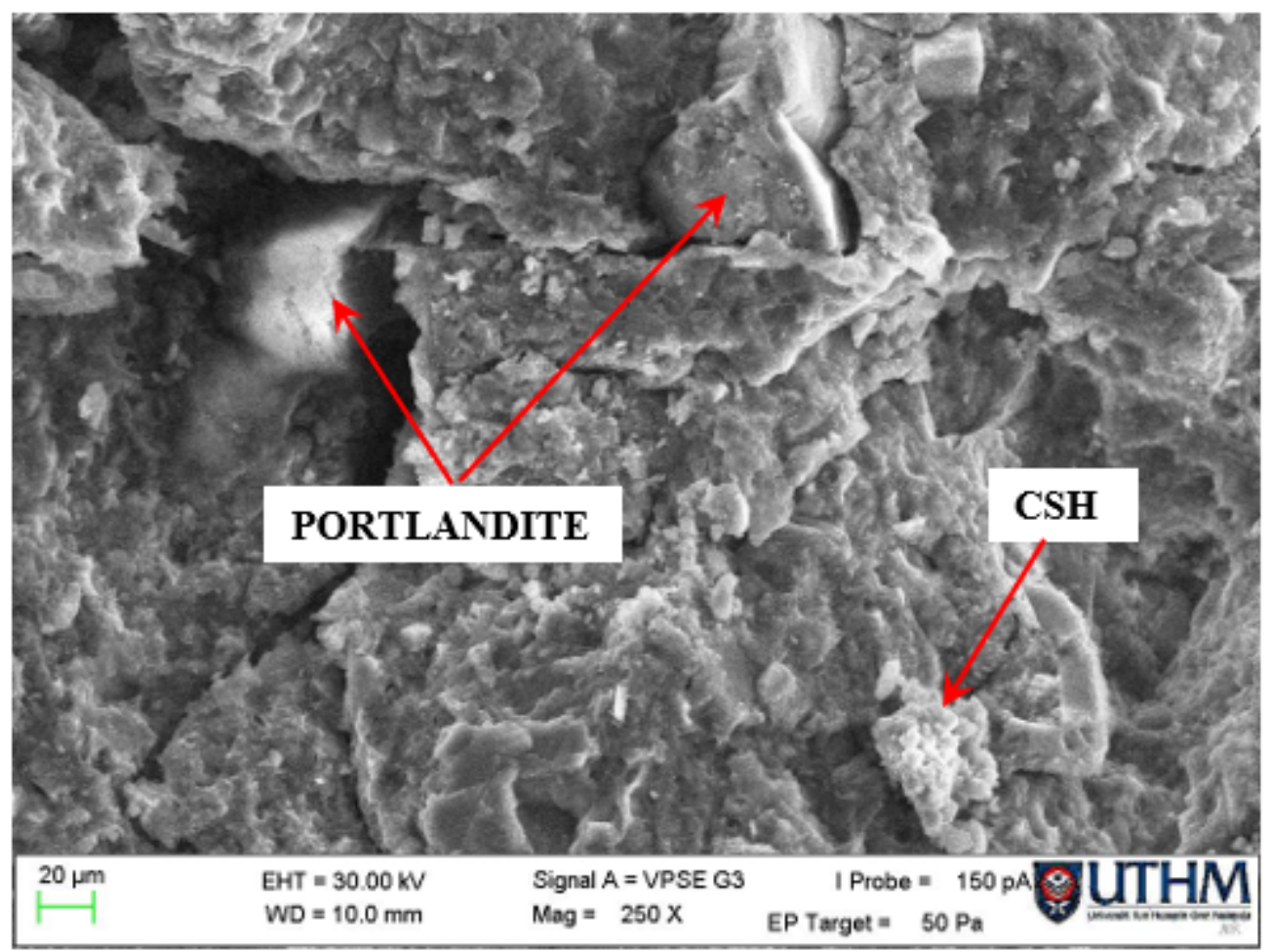

Figure 9 
SEM image of the concrete with CBA exposed to combined solution of $\mathrm{Na} 2 \mathrm{SO} 4+\mathrm{NaCl}$

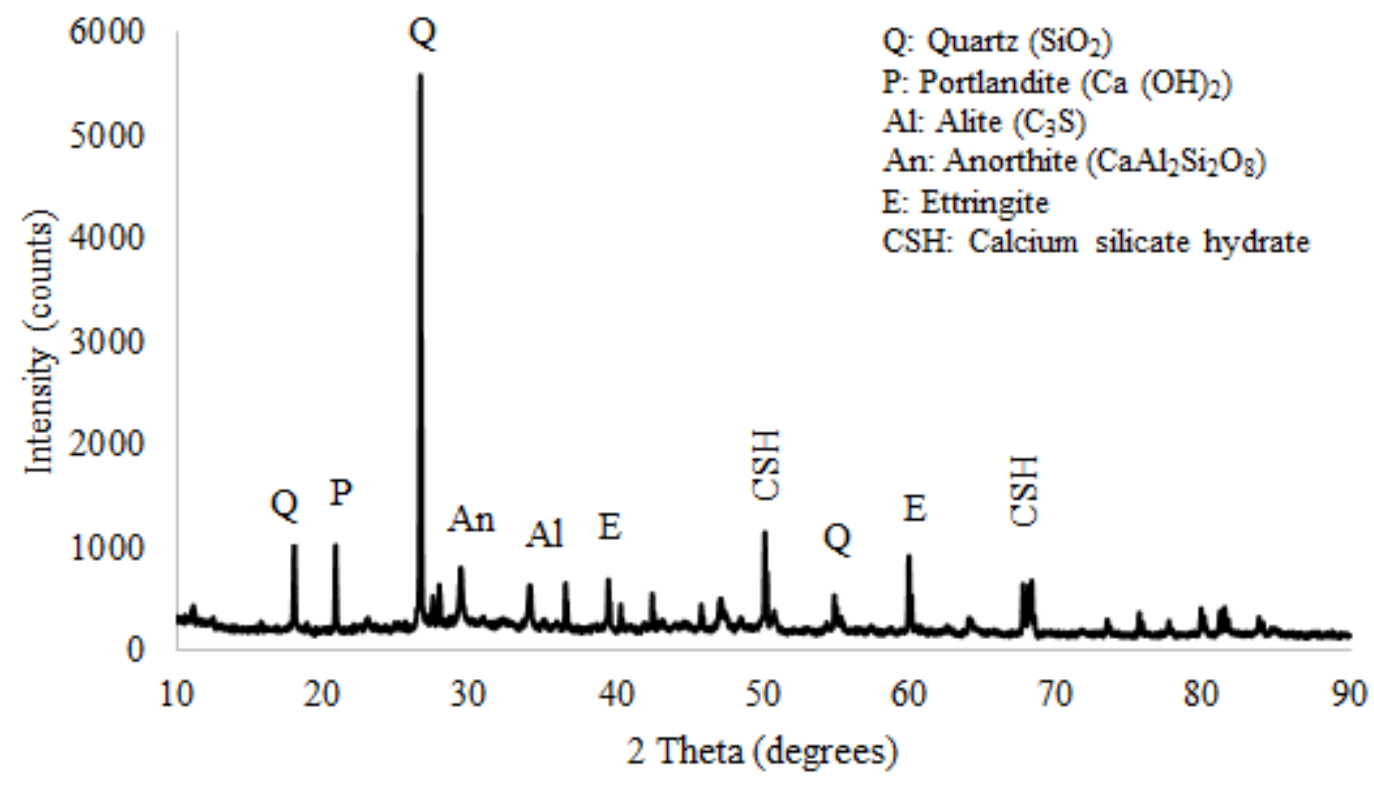

Figure 10

XRD diffraction pattern of $\mathrm{CM}$ concrete exposed to $5 \% \mathrm{Na} 2 \mathrm{SO} 4+5 \% \mathrm{NaCl}$

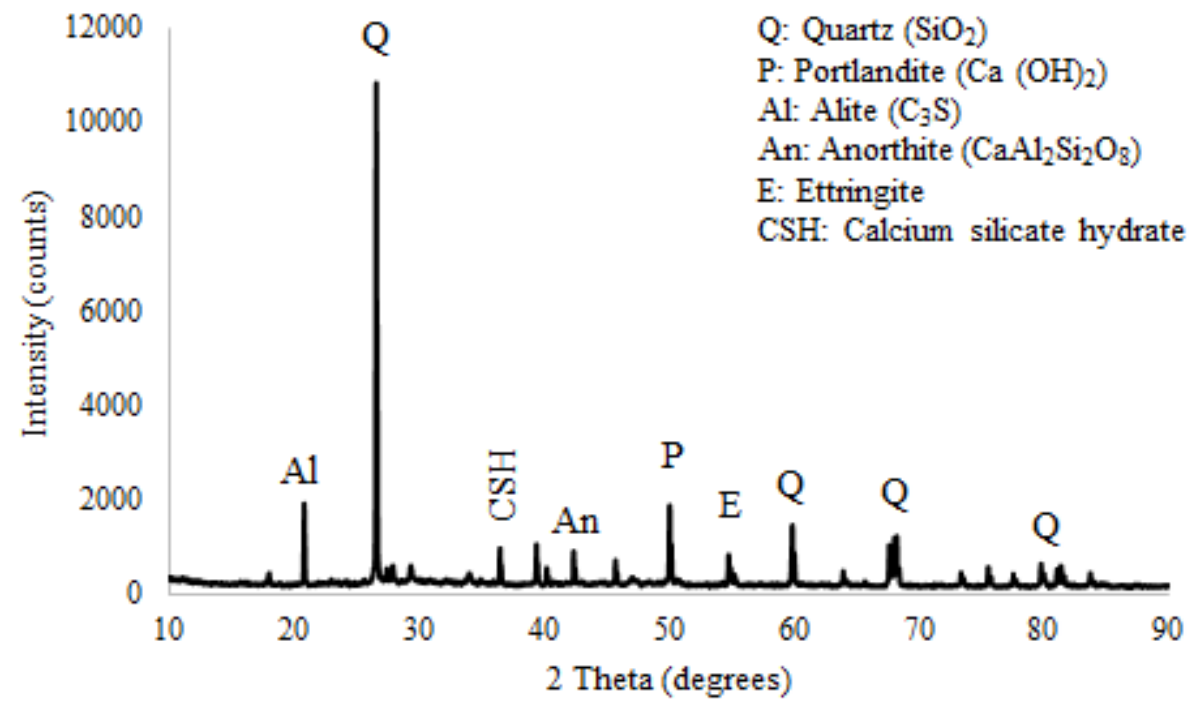

Figure 11

XRD diffraction pattern of concrete with CBA exposed to $5 \% \mathrm{Na} 2 \mathrm{SO} 4+5 \% \mathrm{NaCl}$ 


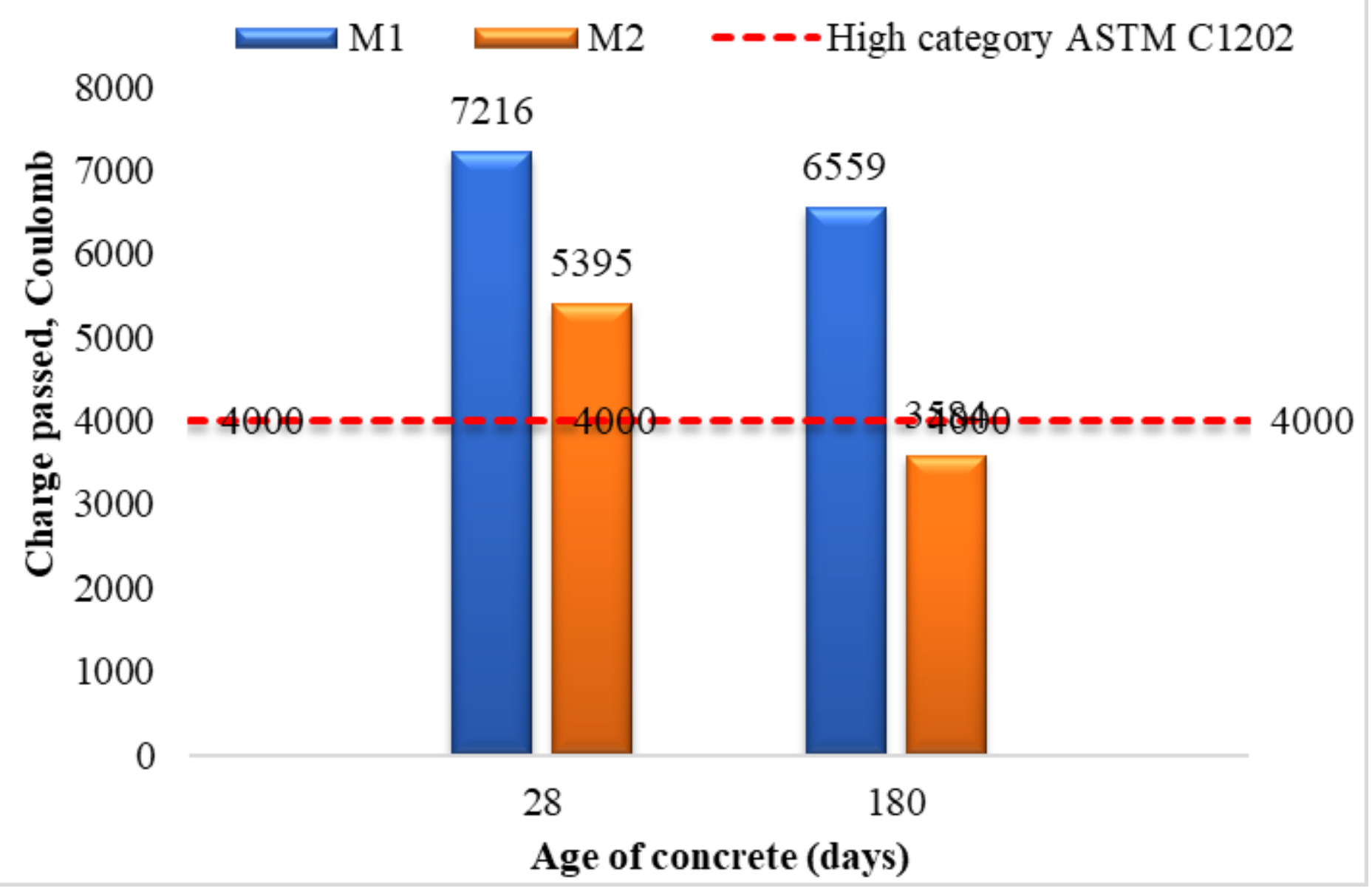

Figure 12

Chloride penetration performance of concrete with and without CBA 


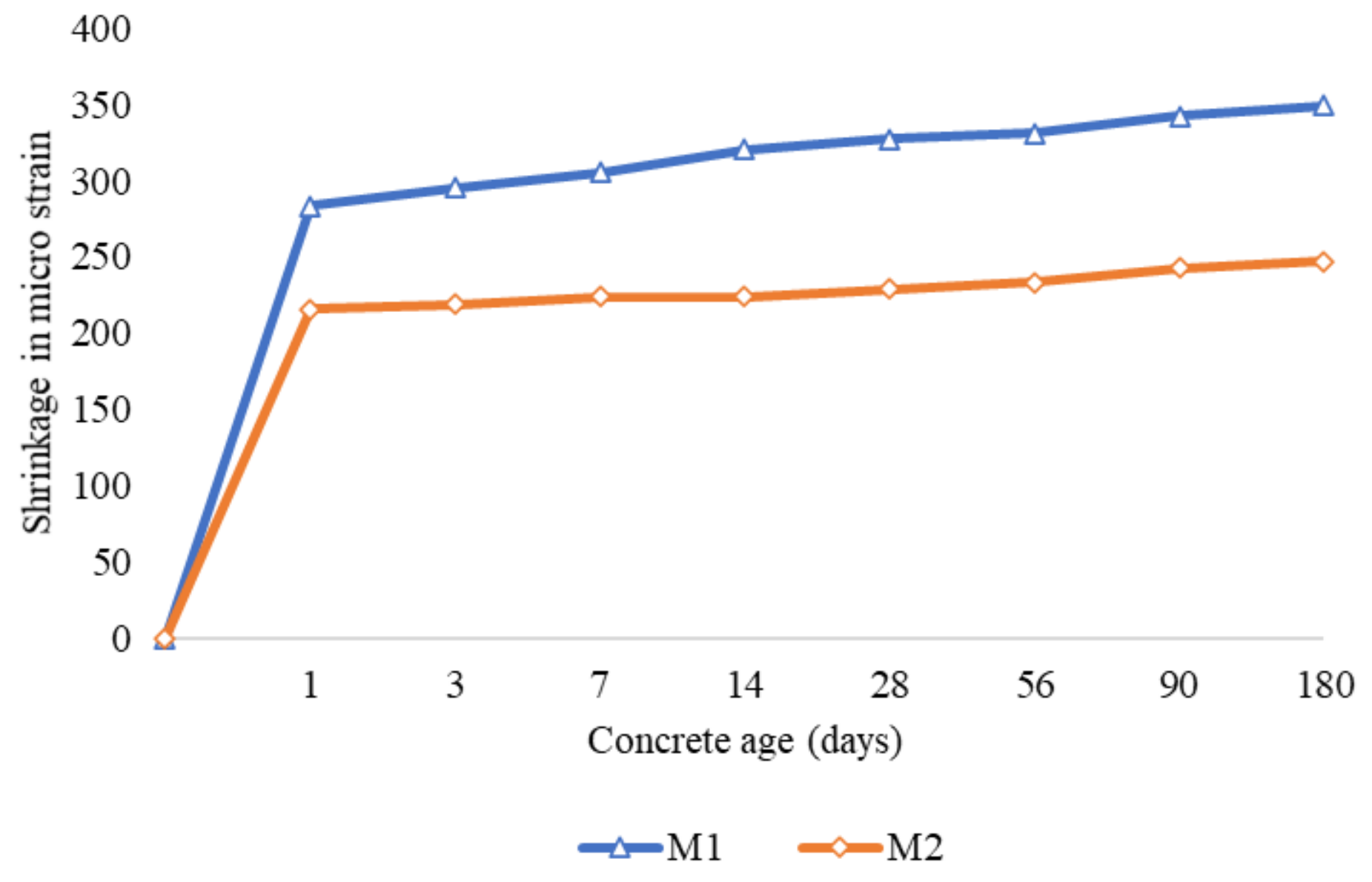

Figure 13

Drying shrinkage performance of concrete with and without CBA 